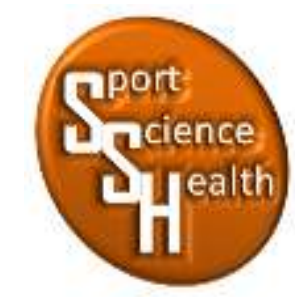

ISSN 2715-3886

\title{
Kontribusi Indeks Massa Tubuh dan Daya Tahan Kardiovaskular dengan Keterampilan Dasar Futsal Sekolah Menengah Atas
}

\author{
Sulton Hartanto Universitas Negeri Malang \\ Hariyoko Universitas Negeri Malang \\ sulton.hartanto29@gmail.com \\ 082333505201
}

\begin{abstract}
Abstrak
Penelitian ini bertujuan mengetahui kontribusi indeks massa tubuh dan daya tahan kardiovaskular dengan keterampilan dasar futsal peserta ekstrakurikuler futsal. Rancangan penelitian menggunakan metode korelasional dengan analisis korelasi product moment. Subjek penelitian peserta ekstrakurikuler futsal berjumlah 33 peserta. Dengan indeks massa tubuh berkontribusi sebesar $53,1 \%$, daya tahan kardiovaskular berkontribusi sebesar $26,9 \%$ terhadap keterampilan dasar futsal. Berdasarkan hasil analisis, dapat disimpulkan bahwa terdapat hubungan signifikan indeks massa tubuh dan daya tahan kardiovaskular dengan keterampilan dasar futsal.
\end{abstract}

\section{Kata kunci}

indeks massa tubuh, daya tahan kardiovaskular, keterampilan dasar futsal

\section{PENDAHULUAN}

Kegiatan ekstrakurikuler menjadi salah satu kegiatan dalam mencapai tujuan pendidikan jasmani. Ekstrakulikuler adalah suatu kegiatan yang dilakukan di luar jam kegiatan aktif (kegiatan tambahan) yang ada di sekolah. Kegiatan ekstrakurikuler yang dilakukan secara baik, tersusun dan berkesinambungan maka dapat meningkatkan keterampilan gerak dasar. Ekstrakurikuler menyajikan kegiatan yang berbentuk olahraga dan non olahraga. Kegiatan ekstrakurikuler merupakan suatu kegiatan yang dilakukan di luar kegiatan inti sebagai sarana untuk memperbanyak pengetahuan dan memperdalam materi yang telah diajarkan oleh pembina ekstrakurikuler kepada peserta didik (Kompri, 2015).

Kegiatan ekstrakurikuler biasanya dilaksanakan sekolah untuk mengisi waktu luang dan mencari siswa yang berbakat dalam bidang tertentu, salah satu kegiatan ekstrakirukuler adalah futsal. Futsal merupakan salah satu olahraga yang populer dan digemari oleh masyarakat, tidak hanya kaum laki-laki tetapi kaum perempuaan juga menggemari olahraga mulai dari anak-anak sampai orang dewasa. Olahraga futsal adalah olahraga yang dimainkan menggunakan kaki, kecuali penjaga gawang dapat menggunakan tangan. Olahraga ini dimainkan oleh dua tim dengan beranggotakan lima pemain dan diperbolehkan dalam setiap tim untuk memiliki 
cadangan. Olahraga futsal merupakan olahraga yang menggunakan lapangan tertutup dan paling banyak diminati semua kalangan (Suryamen, 2016). Futsal dikatakan semacam olahraga sepakbola dalam versi indoor, yang dalam satu dekade terakhir berhasil memperoleh popularitas yang tinggi hamper diseluruh dunia (Abate, 2012). Futsal adalah suatu permainan yang cepat dan dinamis (Amiq, 2014). Permainan sepakbola dalam versi indoor ini dimainkan oleh dua tim yang setaip tim beranggotakan lima orang pemain dan membutuhkan tingkat kompetensi teknik, taktik, dan fisik yang tinggi karena dimainkan dengan waktu yang cepat. Sehingga komposisi tubuh seorang pemain futsal tidak boleh dilupakan, karena futsal membutuhkan energi yang sangat banyak. Indeks massa tubuh yang ideal memiliki peran yang penting dalam melakukan kegiatan olahraga.

Masalah kelebihan dan kekurangan gizi pada orang dewasa usia 18 tahun keatas merupakan salah satu masalah sangat penting (Budiwanto, 2015). Status gizi yang cukup terjadi apabila tubuh memperoleh cukup zat yang digunakan secara maksimal, sehingga memungkinkan untuk perkembangan fisik, otak, kemampuan kerja, dan kesehata. Kekurangan dan kelebihan berat badan juga berpengaruh pada aktivitas seseorang dan harus dipastikan selalu menjaga pola makan yang teratur. Indeks massa tubuh merupakan cara untuk mengukur status gizi seseorang dengan menggunakan rasio berat badan dan tinggi badan dalam satuan kilogram dibagi tinggi badan kuadrat dalam satuan meter.

Selain indeks massa tubuh, daya tahan kardiovaskular dalam olahraga futsal sangat diperlukan karena dapat mempengaruhi kualitas seorang atlet, karena di dalam permainan futsal menggunakan lapangan yang kecil dan dimainkan dengan intensitas yang tinggi dan cepat untuk melakukan gerakan. Oleh karena itu dibutuhkan daya tahan jantung paru yang baik. Daya tahan kardiovaskular yaitu sebagai kemampuan jantung, pembuluh darah, dan paru-paru untuk mengantarkan sejumlah zat-zat gizi dan oksigen kepada sel-sel dalam memenuhi kebutuhann aktivitas fisik yang sedang terjadi dalam waktu yang lama (Budiwanto, 2015). Daya tahan kardiovaskular adalah kekuatan tubuh mengkonsumsi oksigen secara maksimal dalam selang waktu tertentu, dan biasanya dalam satuan menit (Sasmita, 2015).

Dengan demikian olahraga futsal sangat membutuhkan daya tahan kardiovaskular yang baik atau cukup, karena futsal merupakan permainan yang menggunakan intensitas tinggi. Seorang pemain futsal yang memiliki daya tahan kardiovaskular yang tinggi, biasanya pemain tersebut tidak mudah kelelahan dan sebaliknya apabila pemain memiliki daya tahan kardiovaskular yang rendah, maka pemain akan mudah kelelahan saat bermain futsal terutama saat melakukan teknik dasar passing, dribbling, shooting tidak akan baik saat bermain futsal. Berdasarkan wawancara yang telah dilakukan, peneliti mendapatkan hasil kegiatan ekstrakurikuler futsal SMA Negeri 1 Gondanglegi yang dilakukan satu minggu satu kali dengan peserta mencapai tiga puluh tiga dengan rentang usia 15 sampai 18 tahun. Kegiatan ekstrakurikuler ini dilakukan di lapangan futsal SMA Negeri 1 Gondanglegi. Pelatih juga mengiformasikan bahwa banyak peserta yang bukan asli dibidang olahraga futsal melainkan dibidang sepakbola. Maka itu saat kegiatan ekstrakurikuler jarang dilakukan program latian secara teratur atau tersusun, seperti halnya untuk kondisi fisik hanya fokus pada latihan teknik saja. Pelatih belum pernah melakukan tes untuk kondisi fisik kepada peserta ekstrakurikuler futsal khususnya daya tahan kardiovaskular, sehingga pelatih tidak mempunyai acuan atau bukti nyata untuk mengetahui kondisi fisik para peserta ekstrakurikuler futsal.

\section{METODE}

Penelitian ini adalah penelitian korelasional dengan jenis kuantitatif. Subjek penelitian yaitu peserta ekstrakurikuler futsal yang berjumlah 33 peserta. Teknik pengumpulan data berupa data observasi dan dianalisis menggunakan teknik korelasi product moment. Instrumen yang digunakan untuk mengumpulkan data dalam penelitian ini yaitu menggunakan pengukuran indeks massa tubuh, multistage fitness test (bleep test), dan keterampilan dasar futsal.

\section{HASIL}

Data indeks massa tubuh yang digunakan untuk analisis adalah skor dari hasil berat badan dan tinggi badan, daya tahan kardiovaskular menggunakan analisis skor hasil multistage fitness test dan keterampilan dasar futsal menggunakan skor hasil tes keterampilan FIK Jogja. Deskripsi data indeks massa tubuh, daya tahan kardiovaskular dan keterampilan dasar futsal pada ekstrakurikuler futsal disajikan pada Tabel 1 berikut. 
Tabel 1. Deskripsi Data antara Indeks Massa Tubuh (X1), Daya Tahan Kardiovaskular (X2) dan Keterampilan Teknik Dasar Futsal (Y)

\begin{tabular}{cccc}
\hline & $\begin{array}{c}\text { Indeks Massa Tubuh } \\
(\mathrm{X} 1)\end{array}$ & $\begin{array}{c}\text { Daya Tahan } \\
\text { Kardiovaskular }(\mathrm{X} 2)\end{array}$ & $\begin{array}{c}\text { Keterampilan Teknik } \\
\text { Dasar Futsal }(\mathrm{Y})\end{array}$ \\
\hline $\mathrm{n}$ & 33 & 33 & 33 \\
Jumlah & 695,82 & 1706,7 & 1392,56 \\
Mean & 21,09 & 51,72 & 42,20 \\
$\mathrm{SD}$ & 2,54 & 2,50 & 1,96 \\
\hline
\end{tabular}

\section{Keterangan:}

$\mathrm{n}$

$=$ Jumlah Peserta

Jumlah

= Jumlah Skor

Mean

$=$ Rata-rata

SD

$$
\text { = Simpangan Baku }
$$

Berdasarkan Tabel 1 data indeks massa tubuh peserta ektrakurikuler SMA Negeri 1 Gondanglegi dengan jumlah peserta 33 diketahui bahwa jumlah skor 695,82 diperoleh rata-rata (mean) 21,09 dan simpangan baku (SD) sebesar 2,54. Selain itu, dapat diketahui bahwa indeks massa tubuh peserta ekstrakurikuler futsal dengan kategori kurus tingkat ringan 1 peserta (3\%), 30 peserta $(91 \%)$ dengan kategori normal, 2 peserta $(6 \%)$ dengan kategori gemuk tingkat berat, dan tidak ada peserta yang masuk dalam kategori kurus tingkat berat dan gemuk tingkat ringan. Berdasarkan Tabel 1 data daya tahan kardiovaskular peserta ekstrakurikuler futsal SMA Negeri 1 Gondanglegi dengan jumlah peserta 33 diketahui bahwa jumlah skor 1706,7 diperoleh rata-rata (mean) 51,72 dan simpangan baku (SD) sebesar 2,50. Selain itu, dapat ketahui bahwa daya tahan kardiovaskular peserta ekstrakurikuler futsal dengan kategori unggul 2 peserta (6\%), sangat baik 21 peserta $(64 \%)$, kategori baik 10 peserta (30\%), dan tidak ada peserta yang memiliki tingkat daya tahan kardiovaskular dengan kategori sedang, kurang, dan sangat kurang. Berdasarkan Tabel 1 keterampilan dasar futsal peserta ektrakurikuler SMA Negeri 1 Gondanglegi dengan jumlah peserta 33 diketahui bahwa jumlah skor 1392,56 diperoleh rata-rata 42,20 dan simpangan baku sebesar 1,96. Selain itu, diketahui bahwa keterampilan dasar futsal peserta ekstrakurikuler futsal dengan kategori baik 4 peserta (12\%), kategori cukup 21 peserta (64\%), kategori kurang 8 peserta (24\%), dan tidak ada peserta yang memiliki keterampilan dasar futsal dengan kategori baik sekali. Dari uji prasyarat diketahui data yang diperoleh bedasarkan uji normalitas bersifat normal, linear, dan homogen. Setelah dilakukan uji pearson product moment yang menyatakan bahwa nilai Rhitung untuk variabel indeks massa tubuh sebesar $0,862(r \neq 0)$ berarti ada hubungan, sehingga HO ditolak, dapat disimpulkan bahwa terdapat hubungan antara indeks massa tubuh $(\mathrm{X} 1)$ dengan keterampilan dasar futsal $(\mathrm{Y})$. Nilai Rhitung untuk variabel daya tahan kardiovaskular sebesar $0,786(r \neq 0)$ berarti ada hubungan, sehingga $\mathrm{H} 0$ ditolak, dan dapat disimpulkan bahwa ada hubungan antara daya tahan kardiovaskular (X2) dengan keterampilan dasar futsal (Y). Selain itu, juga dapat dilihat signifikan indeks massa tubuh terhadap keterampilan dasar futsal sebesar $0,000<0,05$, dan nilai signifikan daya tahan kardiovaskular terhadap keterampilan dasar futsal sebesar $0,000<0,05$. Dengan demikian terdapat hubungan yang signifikan antara indeks massa tubuh (X1) dengan keterampilan dasar futsal (Y), dan daya tahan kardivaskular (X2) dengan keterampilan dasar futsal $(\mathrm{Y})$.

Tabel 2 Analisis Korelasi

\begin{tabular}{ccccc}
\hline Model & $\mathrm{R}$ & $\mathrm{R}_{\text {square }}$ & Adjusted $R$ Square & Std. Kesalahan \\
\hline 1 & 0,894 & 0,800 & 0,786 & 0,90611 \\
\hline
\end{tabular}

Berdasarkan Tabel 2 menunjukkan bahwa nilai $R_{\text {square }} 0,800$, hal tersebut berarti variabel indeks massa tubuh dan daya tahan kardiovaskular memiliki kontribusi terhadap keterampilan dasar futsal sebesar $80 \%$, sedangkan $20 \%$ dipengaruhi variabel lain yang tidak diteliti atau variabel bebas diluar indeks massa tubuh dan daya tahan kardiovaskular. Selain itu, indeks massa tubuh memiliki sumbangan efektif $53,1 \%$ dan sumbangan relatif $66,35 \%$ paling besar dan daya tahan kardiovaskular memiliki sumbangan efektif sebesar $26,9 \%$ dan sumbangan relatif $33,65 \%$ paling sedikit terhadap keterampilan dasar futsal. 


\section{PEMBAHASAN}

\section{Hubungan Indeks Massa Tubuh dengan Keterampilan dasar futsal Putra}

Berdasarkan hasil analisis yang diperoleh dari korelasi signifikan dalam penelitian ini, indeks massa tubuh merupakan salah satu faktor yang memiliki kontribusi terhadap keterampilan dasar futsal. Nilai signifikan indeks massa tubuh terhadap keterampilan dasar futsal sebasar 0,139<0,05. Maka hal ini menunjukan bahwa korelasi antar dua variabel positif signifikan, karena hasil signifikan indeks massa tubuh lebih kecil dari derajad signifikan. Indeks massa tubuh memberikan sumbangan terhadap keterampilan dasar futsal sebesar $53,1 \%$.

Bedasarkan hasil penelitian indeks massa tubuh memiliki hubungan dengan keterampilan dasar futsal. Terdapat perbedaan antara anak yang mempunyai indeks massa tubuh normal dan anak yang mempunyai ideks massa tubuh gemuk atau kurus terhadap keterampilan gerak dasar (Syahrial Bakhtiar, Khairuddin, 2019). Umumnya kelebihan berat badan pada pemain futsal harus menjadi perhatian penting bagi para staf kepelatihan yang berkerja dalam olahraga tim, karena mengoptimalkan indeks massa tubuh yang harus dianggap sebagai tujuan latihan dan nutrisi untuk meningkatkan kinerja olahraga (Nikolaidis, 2019). Indeks massa tubuh mempunyai hubungan cukup erat dengan keterampilan spakbola diantaranya dribbling, short passing, running with the ball, and heading (Anindito, 2014). Maka dari itu, mempunyai tubuh yang ideal bagi pemain futsal dapat memberikan dampak positif bagi seorang pemain futsal untuk menunjang dan mempermudah untuk melakukan keterampilan dasar futsal. Oleh karena itu, seorang pemain futsal diperlukan mempunyai indeks massa tubuh yang ideal.

\section{Hubungan Daya Tahan Kardiovaskular dengan Keterampilan dasar futsal Putra}

Berdasarkan data yang diperoleh, banyak peserta ekstrakurikuler futsal putrs SMA Negeri 1 Gondanglegi yang mengikuti tim atau klub sepakbola yang berada di Kabupaten Malang. Rata-rata peserta ekstrakurikuler futsal putra SMA Negeri 1 Gondanglegi memiliki tingkat daya tahan kardiovaskular sangat baik. Hasil analisis korelasi melalui uji korelasi antara daya tahan kardiovaskular dengan keterampilan dasar futsal peserta ekstrakurikuler futsal putra, menunjukan bahwa ada hubungan antara daya tahan kardiovaskular dengan keterampilan dasar futsal dan memberikan dumbangan sebesar $26,9 \%$.

Berdasarkan hasil penelitian dari daya tahan kardiovaskular memiliki hubungan dengan keterampilan dasar futsal. Orang yang kebugarannya baik memiliki daya tahan kardiovaskular lebih tinggi dapat melakukan aktivitas lebih kuat dari mereka yang tidak dalam kondisi baik (Ninzar, 2011). Terdapat hubungan daya tahan jantung paru dengan aktivitas fisik yang menggunakan intensitas tinggi (Royani, 2015). Futsal termasuk olahraga dalam kategori aktivitas fisik yang memiliki intensitas tinggi. Futsal termasuh olahraga dalam intensitas tinggi dengan melakukan sprint pendek yang dilakukan dengan intensitas maksimal (Berdejo-delFresno, 2012). Terdapat hubungan yang signifikan antara kapasitas oksigen maksimal terhadap keterampilan teknik dasar sepakbola (Aprizalmi, 2016). Dengan demikian tingkat daya tahan kardiovaskular memiliki hubungan dengan keterampilan dasar futsal. Maka dari itu, pemain futsal harus mempunyai daya tahan kardiovaskular yang baik supaya tidak cepat lelah saat bermain dan pada saat melakukan keterampilan dasar futsal.

\section{Hubungan Indeks Massa Tubuh dan Daya Tahan Kardiovaskular dengan Keterampilan dasar futsal Putra}

Dari hasil analisis indeks massa tubuh dan daya tahan kardiovaskular memiliki hubungan yang signifikan dengan ketrampilan teknik dasar futsal dan meberikan sumbangan sebesar $80 \%$. Oleh karena itu, indeks massa tubuh dan daya tahan kardiovaskular perlu diperhatikan dari diri sendiri, orang tua, dan pelatih. Karena indeks massa tubuh dan daya tahan kardiovaskular merupakan faktor yang menunjang pemain futsal dalam melakukan keterampilan dasar futsal.

Seorang dengan kelebihan berat badan dan lipatan lemak yang banyak cenderung mempunyai daya tahan kardiovaskular lebih rendah dibandingkan dengan seorang yang memiliki lipatan lemak lebih besar (Alamsyah, 2017). Permainan futsal cenderung lebih dinamis dan lebih memerlukan daya tahan jantung paru-paru yang baik, selain itu faktor berat badan dan tinggi badan berpengaruh terhadap prestasi olahraga futsal (Untoro, 2017). Maka itu komposisi pemain futsal tetap harus diperhatikan untuk menunjang permainan individu atau tim. Berdasarkan hasil analisis, diketahui bahwa indeks massa tubuh memiliki hubungan signifikan dengan keterampilan dasar futsal dan memberikan sumbangan efektif sebesar 53,1\%. Adapun daya tahan kardiovaskular diketahui memiliki hubungan signifikan dengan keterampilan dasar futsal dan memberikan sumbangan efektif sebesar $26,9 \%$. Sumbangan gabungan indeks massa tubuh dan daya tahan kardiovaskular 
memiliki hubungan signifikan terhadap keterampilan dasar futsal dan memberikan sumbangan efektif $80 \%$. Dengan demikian, jika seorang pemain futsal memiliki indeks massa tubuh dan daya tahan kardiovaskular baik, maka keterampilan dasar futsal juga akan baik. Oleh karena itu, komposisi tubuh harus tetap terjaga dan tetap menjaga latihan untuk meningkatkan keterampilan dalam bermain futsal.

\section{KESIMPULAN}

Berdasarkan hasil analisis data, dapat disimpulkan bahwa: (1) terdapat hubungan yang signifikan antara indeks massa tubuh dengan keterampilan dasar futsal yang memberikan kontribusi sebesar $53,1 \%$. (2) terdapat hubungan yang signifikan antara daya tahan kardiovaskular dengan keterampilan dasar futsal yang memberikan kontribusi sebesar $26,9 \%$. (3) terdapat hubungan yang signifikan antara indeks massa tubuh dan daya tahan kardiovaskular dengan keterampilan dasar futsal yang memberikan kontribusi sebesar $80 \%$.

\section{DAFTAR PUSTAKA}

Abate, M. (2012). High prevalence of patellar and Achilles tendinopathies in futsal athletes. Journal of Sports Science and Medicine, 11(1), 180-181. Retrieved from http://www.jssm.org

Alamsyah, D. A. N. (2017). Faktor-Faktor Yang Berhubungan Dengan Kebugaran Jasmani Pada Remaja Siswa Kelas Xi Smk Negeri 11 Semarang. Jurnal Kesehatan Masyarakat (e-Journal), 5(3), 77-86. Retrieved from file://C:/Users/LENOVO/Downloads/17169-34887-1-SM.pdf

Amiq, F. (2014). Futsal (Sejarah, Teknik Dasar, Persiapan Fisik, Strategi, dan Peraturan Permainan). Malang: Universitas Negeri Malang.

Anindito, F. (2014). Hubungan Indeks Massa Tubuh Dengan Keterampilan Sepakbola. 1-13. Retrieved from http://jurnal.fkip.unila.ac.id/index.php/JUPE/article/view/4931

Aprizalmi, I. dan. (2016). Hubungan Kapasitas Aerobik (Vo2Max) Terhadap Keterampilan Teknik Dasar Sepakbola Pada Club Getsempena FC Tahun 2016. III, 15-33. Retrieved from https://penjaskesrek.stkipgetsempena.ac.id/?journal=home\&page=article\&op=view\&path\%5B\%5D=25

Berdejo-del-Fresno, D. (2012). Fitness Seasonal Changes in a First Division English Futsal Team. African Journal of Basic \& Applied Sciences, 4(2), 49-54. https://doi.org/10.5829/idosi.ajbas.2012.4.2.537

Budiwanto, S. (2015). Tes dan Pengukuran dalam Keolahragaan. Malang: Universitas Negeri Malang.

Kompri. (2015). Manajemen Pendidikan. Yogyakarta: Ar-Ruzz Media.

Nikolaidis, P. T. (2019). The Relationship of Age and BMI with Physical Fitness in Futsal Players. Sports, 7(4), 87. https://doi.org/10.3390/sports7040087

Ninzar, K. (2011). Study On Solods-to-liquid an Alkaline Activator On Kaolin-based Geopolymers. Journal of Autism and Developmental Disorders, 8-10. Retrieved from file://C:/Users/LENOVO/Downloads/Study_on_solids-to-liquid_and_alkaline_a.pdf

Royani, S. (2015). Prevalence and cause of self-medication in Iran: A systematic review and meta-analysis article. Iranian Journal of Public Health, 44(12), 1580-1593. Retrieved from https://www.ncbi.nlm.nih.gov/pmc/articles/PMC4724731/pdf/IJPH-44-1580.pdf

Sasmita, R. A. (2015). Pengaruh Latihan Zig-Zag Run Terhadap Kecepatan Lari Pemain Futsal Pengaruh Latihan Zig-Zag Run Terhadap. Retrieved from http://eprints.ums.ac.id/35882/1/NASKAH PUBLIKASI.pdf

Suryamen, H. (2016). Pembangunan Sistem Informasi Geografis Lapangan Futsal Kota Padang Berbasis Web. Jurnal Nasional Teknologi Dan Sistem Informasi, 2(1Suryamen, H., Aminuddin, I., Akbar, F. (2016). Pembangunan Sistem Informasi Geografis Lapangan Futsal Kota Padang Berbasis Web. Jurnal Nasional Teknologi Dan Sistem Informasi, 2(1), 45-54. https://doi.org/10.25077/teknosi.v2i1.2016.45-54), 45-54. https://doi.org/10.25077/teknosi.v2i1.2016.45-54

Syahrial Bakhtiar, Khairuddin, H. A. (2019). Pengaruh Strategi Pembelajaran Rangkaian Permainan, Indeks Massa Tubuh Terhadap Keterampilan Gerak Dasar Anak Usia Dini. 4, 1-6. Retrieved from http://sportasaintika.ppj.unp.ac.id/index.php/sporta/article/view/119

Untoro, F. S. (2017). Kelincahan Antara Indeks Massa Tubuh Dengan Kelincahan Dan Volume Oksigen Maksimum Pada Pemain Futsal Mufc Karanganyar. Retrieved from 
http://eprints.ums.ac.id/51823/11/NASKAH PUBLIKASI.pdf

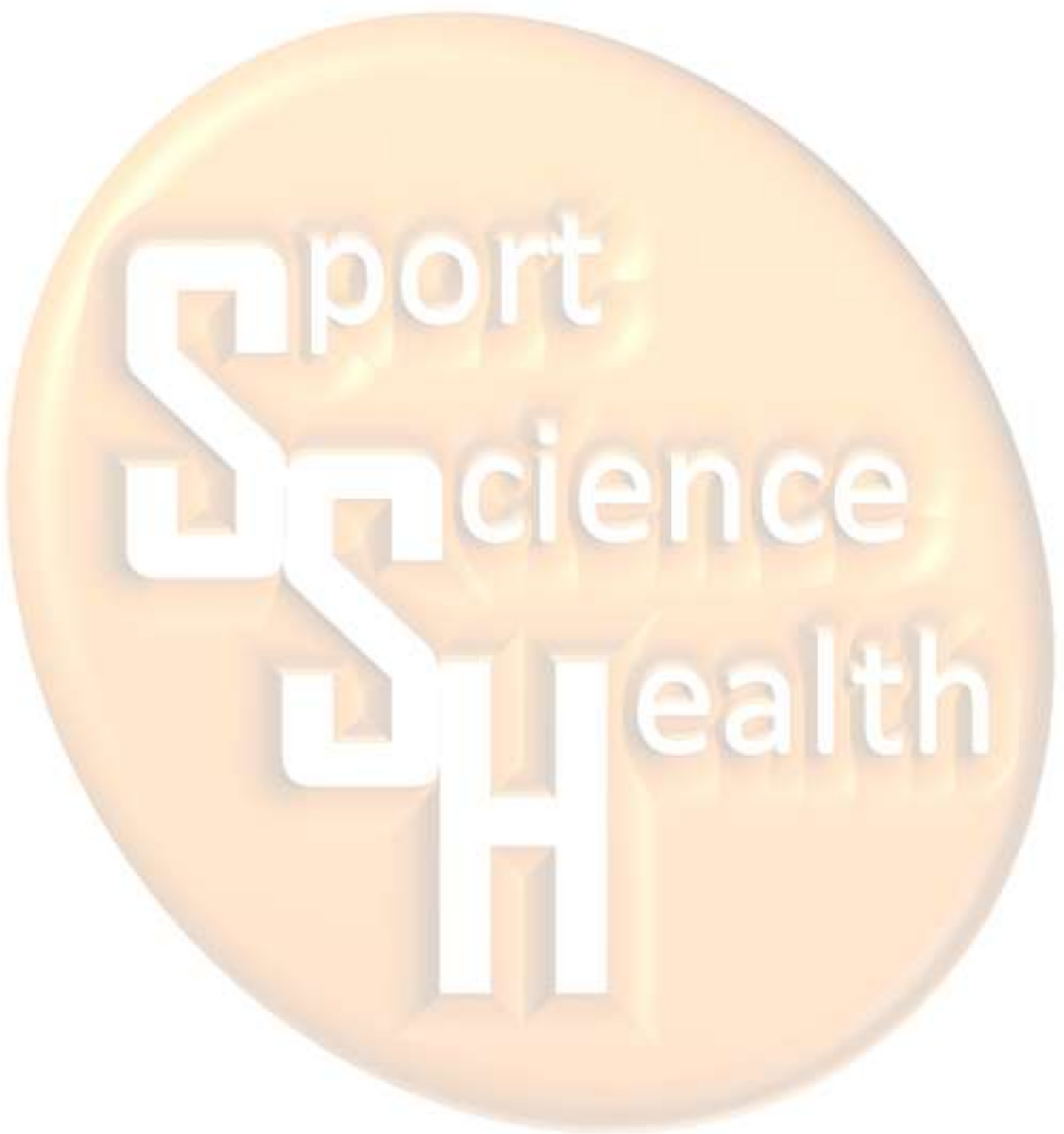

